\title{
Islamization of Banking: What does it mean for Agricultural Financing? - The Case of Pakistan*
}

\author{
By Joachim von Stockhausen
}

\section{Introduction}

Islamization of banking is a phenomenon which can be observed in numerous Islamic countries. A recent example is Pakistan where a comprehensive system of Islamic banking has been introduced. The programme started on a voluntary basis in 1981. Since the middle of 1985, all types of finance to all types of clients can only be provided on an Islamic basis; at the same time, interest-bearing desposits ceased to be accepted. With these decisions Pakistan has made a more radical shift towards Islamic banking than any other Muslim country, including countries such as Iran, Sudan, Egypt and Saudi Arabia. Sceptical observers assume that in practice banks will continue to work on a commercial basis using interest under other names. Such an impression is reinforced if, for example, in the Islamic Banking Manual of the Agricultural Development Bank of Pakistan one reads that: "Similarly against only one name for return, that is, Interest", now there will be various names, like, Profit, Dividend, Rent, Mark-up, Mark-down, Charge etc.".

Islamic banking brings many changes in the modes of agricultural financing. It has consequences for the mobilization of rural savings and implications for the character of rural banks. These consequences are the object of this paper.

\section{Philosophy of Islamic Banking}

Though the appellations Interest-Free Banking and Islamic Banking are often used interchangeably there is a basic difference between the two concepts. While Interest-Free Banking is a mechanical concept denoting a specific mode of banking, Islamic Banking is essentially normative and defined as a conduct of banking in consonance with the ethos of an Islamic economic system.

As stated by the Council of Islamic Ideology of Pakistan, the main rationale for prohibition of interest stems from the concept of justice between man and man as the corner-

* The author gratefully acknowledges helpful comments from Mr. S. Y. Zaidi, Director of the State Bank of Pakistan. 
stone of the Islamic philosophy of social life. There are various schools of thought who interpret "Ribah" (interest payments and receipts) free financial transactions (trading) in the present-day world differently. Following Zaidi, the fundamental distinction between 'Ribah' and trading as enunciated in Islam appears to be based on one fundamental principle - whether or not the relationships between individuals or between institutions are based on risk free or risk sharing arrangements. ${ }^{1}$

There are three criteria which are required for evaluating the appropriateness of a banking structure. First, does it really achieve the elimination of "Ribah" as enjoined by Islam? This criterion refers to the different modes of Islamic financing and the reward on savings. Second, is the banking structure conducive to the Islamic economic structure that is envisaged? At the moment, no blue-print of an Islamic economic system has been worked out. The Naqui Report on Islamization published in May 1980 states that nothing more than a mere smattering of vague ideas of "Zakat" (formerly a religious levy but now also a state levy and compulsorily collected) and "Ribah" have been formulated and in June 1984 a Pakistan daily said that after six years of discussions of the basic principles of Islamic economics no consensus has evolved beyond stating that "Zakat" and abolition of interest are the two pillars of the Islamic economy. ${ }^{2}$ Although, as mentioned above, the abolition of interest is a necessary condition for an Islamic order, it seems by no means a sufficient one. Zaidi refers to the ethics in Pakistani society by raising the question whether it is practical to expect a successful transition to an interest free system taking place within a foreseeable future if people are more concerned with their material well-being than moral values; the interest-bearing system is dominating the banking system either because of the moral hazards or because of the problem of dishonesty on the part of the entrepreneurs borrowing funds from the financial institutions. ${ }^{3}$

The third evaluation criterion regards the question whether the banking structure is viable and stable. It is emphasized that a balance has to be attained between borrowers, banks and depositors. It is this balance which has to safeguard the interests of the depositors and to provide to them some earnings and incentives to save.

\section{Modes of Islamic Financing}

The Islamic Banking System introduced in Pakistan distinguishes between three groups and twelve modes of financing: ${ }^{4}$

1 S.Y. Zaidi, "Interest Free Banking: Problems and Prospects", Journal of the Institute of Bankers in Pakistan, March 1986, pp. 27-28.

2 H. Habib, "Replacing Capitalism by Capitalism", Pakistan \& Gulf Economist, August 4-10, 1984, pp. 21-23.

3 S.Y. Zaidi, 1986, op. cit., p. 34.

4 State Bank of Pakistan, Elimination of Interest from the Banking System in Pakistan, Karachi 1984, p. 3. 
(A) Financing by lending:

(i) Loans not carrying any interest on which the banks may recover a service charge not exceeding the proportionate cost of the operation, excluding the cost of funds and provision for bad and doubtful debts. The maximum service charge permissible to each bank will be determined by the State Bank from time to time.

(ii) "Quard-e-Hasana" loans given on compassionate grounds free of any interest or service charge and repayable if and when the borrower is able to pay.

(B) Trade-related modes of financing including the following:

(i) Purchase of goods by banks and their sale to clients at appropriate mark-up in price on a deferred-payment basis.

(ii) Purchase of trade bills.

(iii) Purchase of movable or immovable property by the banks from their clients with Buy-Back Agreement or otherwise.

(iv) Leasing

(v) Hire-purchase

(vi) Financing for development of property on the basis of a development charge.

(C) Investment type modes of financing. These modes include the following:

(i) "Musharika", or profit and loss sharing.

(ii) Equity participation and purchase of shares.

(iii) Purchase of participation term certificates and "Modaraba" certificates ("Modaraba" means a business in which a subscriber participates with his money, and the manager, or "Modarib", participates with his efforts and skills, and profits on investments made out of the "Modaraba" Funds are distributed among the subsribers).

(iv) Rent-sharing.

Loans on service charges are mainly used for inter-bank financing. Financing provided by the State Bank to the Agricultural Development Bank of Pakistan (A.D.B.P.) and to the Federal Bank for Cooperatives is based on this mode. The method of calculating the service charge is demonstrated in Table 1 . The value calculated comes close to that of the A.D.B.P. with $3.58 \%$ for the year ended the 30th June, 1984.

These modes of financing are by no means Islamic by definition. They contain aspects which can easily turn them into usurious transactions: ${ }^{5}$ For instance, a bank may participate in a project through a hire-purchase agreement with collateral securities for performance of the contract by way of promissory notes provided by the partners of share-holders. Both transactions, considered separately, would appear to be valid, but taken together the contract may be designed as to ensure that in case of default the bank receives its full investment via the promissory notes and mulcts the client with all the

5 S.Y. Zaidi, 1986, op. cit., p. 37. 
losses. To make hire-purchase Islamic, some sort of protection of the shareholders is necessary.

Or, take the case of mark-up financing. Mark-up is a sale in which the margin of profit, or mark-up to the seller, is mutually agreed upon in advance between the buyer and the seller. But what happens if a mutual agreement is not possible because of the seller being a monopolist? In this case the Government is asked for intervention to maintain the public interest. This example shows that limiting the maximum profit/return by governmental intervention is not only a task of determining factor allocation but moreover an activity of keeping financing Islamic.

\section{Agricultural Financing}

The main modes of agricultural financing are interest-free loans, mark-up loans and, exclusively for medium and long-term financing, leasing and hire-purchase.

Interest-free loans date back to the pre-Islamization phase. In 1979-80, the Government of Pakistan decided that the commercial banks should advance interest-free production loans to small farmers to meet their credit needs in respect of fertilizers, seeds, and pesticides up to Rs. 5,000 per farmer. In the meantime, the maximum amount has been increased several times. 1985, it was Rs. 10,000 per farmer per year, subject to a limit of Rs. 800 per acre. An agricultural credit survey from 1983 shows that $29 \%$ of the total number of loans were obtained by large farmers interest free, to which they were not entitled; the corresponding loan amount stood at $23 \% .^{6}$

The most common mode of agricultural financing are mark-up loans which belong to the trade-related modes of financing. Mark-up loans may be defined as a sale in which the margin of profit is mutually agreed upon between the buyer and the seller and the agreed price of the item involved is payable on a deferred basis either in a lump-sum or in instalments. To be in conformity with "Sharia", (codification of the injunctions of the Holy Quran) it is necessary that the item should come in possession of the bank before being handed over to the other party; for this purpose, it would be sufficient if the supplier from whom the bank has purchased the item sets it aside for the bank and hands it over to any person authorized by the bank on its behalf. For instance, if the current cost of a bag of fertilizer to the bank is Rs. 50 the bank may sell it, through its agent, to a farmer needing bank finance at Rs. 55 subject to actual payment of this price after an agreed period. The bank would, however, pay Rs. 50 to its agent prior to or immediately after the supply of the fertilizer under the bank's instruction.

As from the 1st April, 1985, the Government of Pakistan has decided to subsidise the

6 National Fertilizer Corporation of Pakistan Limited, Agricultural Credit Study in Pakistan, Karachi 1983, p. $x x v$. 
element of mark-up in cases of prompt payment. Therefore, each input has three prices, i. e. (i) the cash price which would be the cost of the input to the bank; (ii) the credit price which would be the sale price payable by the farmer; and (iii) the prompt payment price which would be the price payable by the farmer if he pays the sale price within the prescribed period.

For small farmers, the credit price is $14 \%$ above the cash price and the prompt payment price $10 \%$ above the cash price. Subsidy payable by the State Bank of Pakistan to the lending bank is the difference between the cash price and the prompt payment price. In case of repayment delay, the farmer has to pay the full credit price and no subsidy is granted.

As a trade-related mode of financing mark-up loans are only given in kind. Although loans in kind are used world-wide to prevent misuse of loan funds by borrowers this form of intervening agricultural credit policy is increasingly criticized for causing insufficient agricultural financing. The necessity of cash loans is also well acknowledged in Pakistan and the State Bank has started the initiative to loosen the strict character of mark-up loans by allowing the farmer-borrower to opt for a certain percentage of the finance in cash.

Leasing and hire-purchase are two modes of financing exclusively used for medium and long-term financing of agricultural assets. Both modes of financing can be defined as techniques of providing medium and long-term financing for acquiring assets on a deferred payment basis.

Lease financing can be distinguished between full pay-out or finance lease and operating lease. With regard to the former, rentals during the fixed period are sufficient to amortize the capital outlay of the lessor and provide an element of profit; the ownership of the assets is transferred to the lessee and his option on payment of the nominal residual value is determined by the lessor. In operating lease, rentals are not sufficient to amortize the capital outlay of the lessor during the lease period and the lessee has no option to purchase the asset.

In both cases, the lessee is responsible to keep the assets in proper operating conditions and bears all costs towards running, maintenance and repair.

The assets acquired with hire-purchase financing remain under a joint ownership of the bank and the client or may be owned by the bank alone; they are passed on to the hirer after the amount of acquisition value and the agreed rent is paid in full.

The Islamic modes of financing clearly show that banks' funds are exposed to comparatively high risks and partly to a reduction of income, on account of the elemination of compounding of return, of charging no return for the period of default, of charging no penal return in the event of default, and of charging no return for the period of rescheduling. Although these basic principles of Islamic financing are partly undermined by the mechanism of subsidizing the mark-up, it has to be stated that the banks' risks are higher than in an interest-bearing credit system. Having these risks in mind, Khan stresses the importance that banks should take utmost care in assessing (i) the creditworthiness of the clients, (ii) the marketability of the commodities sold or goods manufactured there- 
Table 1: Calculation of the Service Charge (Figures in Million of Rs.)

1. Total Expenditure (total income less balance of profit i. e. gross profit, as per audited Profit and Loss Account)

2. Less:

(i) Interest and return on deposits, borrowings etc.

(ii) Income taxation and provision for it if charged to Expenses Account

(iii) Bad assets provision and write-offs by direct debit to Expenses Account

(iv) Total of (i) to (iii)

3. Administrative Expenditure (1 minus 2 (iv))

4. Total assets at the beginning of the year

5. Total assets at the end of the year

6. Average of the total assets at the beginning and end of the year

Service Charge in percentage terms to the nearest decimal point

( 3 divided by 6 and multiplied by $100=1,100 \times 100=3.4 \%$

$$
32,000
$$

Source: State Bank of Pakistan, Elimination of Interest from the Banking System in Pakistan. Karachi 1984, p. 9.

Table 2: $\quad$ Rates of Return on PLS Deposits (\% per annum)

Modes of Deposits

Six-months period ended

December, 1984

June, 1985

Special Notice Deposits

. 7 to 29 days

$5.20-6.60$

$4.90-8.70$

. 30 days and over

$6.15-7.85$

$5.60-11.40$

Savings Accounts

$7.10-9.70$

$7.50-13.30$

Term Deposits

$9.00-15.75$

$8.60-21.60$

(Three Months)

Source: State Bank of Pakistan, Annual Report 1984-85, p. 84 
from, (iii) the cash flow chart, and (iv) the securities offered to doubly ensure that payment would be forthcoming by the due date.?

\section{Savings Mobilization}

As from January, 1981, all branches of nationalized commercial banks started accepting deposits on a profit and loss sharing basis. From the middle of 1985, Pakistani banks do not accept any deposits based on interest. Savings accounts are only accepted on a profit and loss basis, and in case of current accounts no profit is given to the depositors. Banks receiving PLS deposits have to declare rates of profit on various types of their PLS deposits on a half yearly basis. The income allocated to PLS deposits is restricted to non-interest incomes. The calculation method of net non-interest income and its distribution on different types and maturities of non-interest liabilities is prescribed in detail by the Banking Control Department of the State Bank of Pakistan. ${ }^{8}$

The restriction of non-interest income distributable on PLS deposits has the consequence that if the non-interest earning assets are low as compared to PLS deposits, the rate of return on such deposits will be low as in such a situation a part of the funds will remain unutilized. Therefore, the Banking Control Department requests banks to watch carefully the growth of PLS deposits and to ensure that their investments in non-interest bearing assets are substantially higher than the deposits; if for any reason this is not feasible at any stage, the unutilized funds should be deposited with the State Bank on PLS basis.

During 1984-85, deposits under the profit and loss sharing (PLS) scheme registered a sharp increase of Rs. 16.0 billion compared with a rise of Rs. 7.9 billion during the preceding year. On 30th June, 1985, the outstanding level of deposits under PLS system was 27.6 per cent of the total deposits as compared with 18.7 per cent a year earlier. The rates of return on PLS deposits are given in Table 2. Compared with the rise of the Wholesale Price Index of 10.5 per cent in $1983-84$ and 3.7 per cent in $1984-85^{9}$ the rates of return are comparatively high. This is also true if the rates of return are compared with the credit price of mark-up loans of $14 \%$ p.a.

Discussion is controversial with regard to the question of how depositors will react to the abolition of interest; the importance of this question is reflected in the fact that during the period 1983-84 till 1984-85 the gross national savings ratio in Pakistan was not only rather low but also decreased from 4.3 to 3.9 per cent of the Gross Domestic Product (at current market prices).

7 A. J. Khan, "Elimination of 'Riba' from the Banking System", Journal of Islamic Banking \& Finance, Vol. I, 1984, No. 3, p. 32.

8 State Bank of Pakistan, 1984, op. cit., pp. 14-23.

9 State Bank of Pakistan, Annual Report 1984-85, p. 117. 
A rather optimistic view is expressed by Fakrul Ahsan. To him deposits are not wholly or largely dependent on the rate of interest, but considerations of security, safety, service and convenience play very important rôles in drawing the community's money to the organized banking system. ${ }^{10}$ The experiences of the Indian Syndicate Bank, however, show that the interest rate plays a neglible role only in so far as very small deposits are concerned. Under the pigmy deposit scheme, the Syndicate Bank arranged to collect small sums of money on a daily basis from the door-steps of the prospective customers. The attractiveness of this scheme is not the rate of interest, but the convenience of operation. This is explained on the ground that for the dribblets of savings, there is no other avenue of investment available and the opportunity cost is zero. ${ }^{11}$

A different concept of savings starts from the religious point of view. It is argued that fixed interest rates on deposits are rejected by the population as they are looked upon as un-Islamic; Muslims refuse to deposit their savings with a bank because they get a fixed interest rate. To a certain extent, this argument is empirically verified by a recent analysis of constraints faced by banks in deposit mobilization, placed in the North West Frontier Province: ${ }^{12} 12.5$ per cent of the bank branches identified as a constraint that interest on deposits is conceived as un-Islamic.

A completely different position is taken by Jafarey: ${ }^{13}$ If the Government desires to mobilize domestic savings, then while conforming to the general principles of Islam that there shall be no exploitation, there should be no hesitation in evolving and enforcing a scheme which ensures profit within a reasonable range. The psychological need for security would be fulfilled when profit is assured at a rate ahead of inflation. It is his opinion that fixed returns by the Government within a specific range do not appear to be un-Islamic.

Similar to Jafarey, Western economists also stress the security aspect. Islamic financial institutions should look for workable schemes which, though they do not guarantee the return on PLS deposits, do at any rate protect the sum initially deposited. "At least in theory, one feasible method could be the insurance of the sums deposited by an institution unrelated either to the bank or to its customers". ${ }^{14}$

10 A.S.M. Fakrul Ahsan, "On the Nature and Significance of Banking without Interest", Bangladesh Bank Bulletin, Vol. 56, February 1978, p. 5.

11 N.K. Thingalaya, "Innovations in Banking: The Syndicate's Experience". The World Bank, Domestic Finance Studies No. 46, Washington D.C. 1978, p. 11.

12 S.Y. Zaidi, "Rural Savings Mobilization in Pakistan", Journal of the Institute of Bankers in Pakistan, December 1985, p. 34.

13 N.H. Jafarey, "Mobilization of Domestic Savings in an Islamic Economic System", Pakistan \& Gulf Economist, August 4-10, 1984, p. 16.

14 V. Nienhaus, "Principles, Problems and Perspectives of Islamic Banking", Intereconomics, September/October 1985 , p. 237. 


\section{Changing Character of Islamic Banks}

To be in conformity with Islamic economics the character of banks will change. The Islamic modes of financing makes it necessary that the banks become more involved in the projects than before. Especially with investment type modes of financing but also with granting mark-up loans and financing assets on a hire-purchase or leasing basis the banks are directly involved in trading: The banks have to see whether the financed inputs are there and whether the prices are right because they have to buy the commodities and resell them.

The banks lose their character as simple retailer of money and acquire that of a partner with greater responsibility for the viability and profitability of the projects into which they enter. They will become more responsible for the profitability of farmers' investments by providing investment goods and inputs in time as well as by granting information and expertise.

This changing character is an opportunity and a danger to the banks' farmer clients at the same time. A chance in so far as it widens the developmental responsibilities of the banks making them more efficient to overcome the bottlenecks of farmers' development. A danger is seen in two ways. First, the widening responsibilities of the banks strengthen their power and may lead to its misuse, the institutions being more concerned with their own profit than with serving the interests of rural society. Moreover, due to a lack of expertise with regard to the varieties of trades/industries the banks could try to evade the higher risk by refusing finance, by offering financial terms which make the envisaged projects unfeasible or by asking collateral which surpasses the capabilities of the clients.

For assessing such a behavior a further aspect has to be considered. According to the Quran the Muslim community is placed under an obligation to extend time for repayment of loan in case a person is unable to return it due to some stringencies. This Islamic principle has to be seen in connection with the prohibition of taking compound interest. For solving this problem Zaidi proposes a national fund to which every person involved in the business of lending or borrowing could contribute. In time of need this fund could provide an insurance cover for the needs of the borrower or the creditor. ${ }^{15}$ It is easy to see that in case of losses disputes on responsibility will arise. For solving this problem, the Government of Pakistn promulgated the Banking Tribunal Ordinance in 1984. This ordinance transferred to the Tribunals certain powers like civil jurisdiction in respect of a claim filed by a banking company against a customer arising out of finance provided by it. The Tribunals shall decide each case within a maximum period of 90 days.

A specific impulse for controlling the activities of the banks comes from the side of savings mobilization. In the past, the banks' expansion policies failed to realize the potentials in deposit mobilization in rural areas because of their conservative outlook. No proper link was established between the provision of credit and deposit-taking.

15 S.Y. Zaidi, 1986, op. cit., p. 49. 
Strengthening such a link could mean that depositors obtain a stronger right to control how their deposits are going to be used. This means that the philosophy of Islamic banking has institutional implications which are in harmony with a stronger participation of the rural population in the development process as a condition for justice, benevolence, liberty and freedom of choice, brotherhood and social equality of man as basic elements of the Islamic way of life. ${ }^{16}$ At the moment, no such institutional arrangements for Islamic banks exist in Pakistan; the implementation of Islamic principles and the balance to be obtained between credit clients, banks and depositors, however, should tend to give savers a stronger opportunity to observe what is done with their funds. Such a form of savers' participatory control via representatives on the board could compensate for non-interest payment by sharing in the growth of the local community that has taken place by the activities of the banks.

It is a question of practical experience whether such a link between depositors and banks will have positive repercussions on business morality and competence. In any case, the necessity of safeguarding the intersts of the depositors brings an impetus into the institutional framework of Islamic banks which is in line with the principles of co-operatives as defined by F.W. Raiffeisen. It would be wrong, as Raiffeisen states, to believe that the set-up of savings and credit associations would change the lamentable circumstances. It is the spirit which has an animating effect. Without the moral forces, i. e. without recognizing and accepting the duties towards our fellow-men a prosperous development of the associations is nearly impossible.

Although Islamic banking offers rather good incentives for institutional reforms in rural banking which fit to the needs of the rural population, there are some signals which make one sceptical as to whether reforms will really take the direction envisaged. For example, as a reaction to the announcement of the State Bank of Pakistan to cease accepting interest-bearing deposits since July, 1985, the Agricultural Development Bank of Pakistan only accepts deposits in current accounts. The decision not to accept PLS accounts is explained in such a way that otherwise it could happen that depositors receive a higher return than the borrowers have to pay for the loans. Such reasoning is mainly explained by the bank's strongly subsidized refinancing and by an agricultural credit policy which has a tendency to prefer larger projects. which cause lower bank's loan transaction costs.

However, there is one more fundamental argument to be considered. And this is the controversial discussion on the rôle of the State in Islam. On the one side, it is argued that the State has to ensure social security and provide for basic needs of the people. This implies that the State can control business activities, and fix prices, wages and rents. On the other side, it is said that the objectives of an Islamic State can be better served by education and indoctrination and coercion should be used only as a last resort if education fails. 
Although it is felt that governmental control over banks and erosion of their autonomy have been a major handicap it is stressed at the same time that private banks have failed to play a positive role in the social well-being of the people. Their failure in providing rural credit for an agrarian economy was only matched by their reluctance to invest in low-cost housing or other welfare projects. ${ }^{17}$

If this view is correct, the balance between borrower, bank and depositor has to be safeguarded by the State, in other words, the risk problem of depositors has to be solved by the government by implementing adequate insurance systems. However, such a solution raises the question of whether the premium of such an insurance is in harmony with Islamic principles. The Islamic Fiqah Academy recently decided that any commercial insurance with a fixed premium was "Haram" (usury), for Muslims. At the same time it resolved that the question whether insurance run on a cooperative basis was Islamic needed full discussion and further research. ${ }^{18}$ If this question is positively answered it would be a strong argument for private rural banking.

\section{Conclusions}

The principal task of the Islamization of banking is to devise an institutional framework and to design a variety of financial instruments which conform to the teaching of Islam and also aim at the optimum distribution of savings to meet the requirements of investment financing in an Islamic economy. In Pakistan, Islamization is seen as a pragmatic approach; the exact form it will take depends on practical experience to be gained and the knowledge to be derived from ongoing discussions.

The specific feature of Islamic Banking is that unlike interest the return by way of profit is not predetermined and fixed but is uncertain and variable. The sharing of profit between the providers and users of funds on a mutually agreed basis is the strongest challenge of Islamic Banking. Considered as an institutional development process it means that the banks have to become a real part of rural society. The rural people must consider the banks as theirs and the banks have to identify themselves with the problems of rural society.

At the moment, the main sources of agricultural credit in Pakistan are the nationalized commercial banks with $43 \%$, the Agricultural Development Bank of Pakistan with $42 \%$ and the co-operatives with $15 \%$. Compared with the attention paid to the shaping of the different modes of Islamic financing and the reward on savings, there is nearly no discussion whether the existing organizational structure of agricultural credit is optimal with regard to Islamic banks and agricultural development. These organizational aspects seems to deserve greater attention in order to make farmers and banks real partners.

17 "Banks in private sector". Editorials. Pakistan \& Gulf Economist, June 22-28, 1985, pp. 6-7.

18 "Interest on loans declared "haram", Business Recorder, January 13, 1986. 
African states are found to focus their interests excessively on the Lomé agreement whereas the GATT provides a set of multilateral rules relevant also to all non-EEC trade. The forthcoming "Uruguay Round" of multilateral trade negotiations, which is to produce new rules in various fields of trade, constitutes a particular challenge for a more active participation of Africa, to prevent the erosion of preferential rules (graduation) and to achieve better conditions of market access worldwide.

\section{Islamization of Banking: What Does It Mean For Agricultural Financing? - The Case of Pakistan}

\section{By Joachim von Stockhausen}

Islamic banking brings many changes in the modes of agricultural financing. It has consequences for the mobilization of rural savings and implications for the character of rural banks.

The Islamic Banking System introduced in Pakistan distinguishes between three groups and twelve modes of financing. The main modes of agricultural financing are interestfree loans, mark-up loans and, exclusively for medium and longterm financing, leasing and hire purchase.

From the middle of 1985, Pakistani banks have not accepted any interest-bearing deposits; savings accounts are only accepted on a profit-and-loss basis. Discussion is controversial with regard to the question of how depositors will react to the abolition of interest. There is a strong body of opinion holding that, for avoiding exploitation of the depositors, a scheme has to be devised which ensures profit within a reasonable range. Trying to conform to Islamic economic doctrine and considering the comparatively high risks of Islamic modes of financing, the banks have lost their character as simple retailers of money and acquired that of partners with greater responsibility for the viability and profitability of the ventures into which they enter. Moreover, to give savers a stronger opportunity to observe what is done with their funds, there is a specific impulse for control of the banks' activities by the depositors. This means that the philosophy of Islamic banking has institutional implications which are in harmony with a stronger participation of the rural population in the development process. At the same time, however, there are some signs which make one sceptical as to whether institutional reforms will really take the direction envisaged. The organizational aspect of a proper balance between borrower, bank and depositor seems to deserve greater attention in order to make banks a real part of rural society. 